\title{
Detection of bacterial species associated with periodontal disease in a group of patients
}

\author{
Detectarea speciilor bacteriene asociate cu boala parodontală la un lot de pacienți
}

\author{
Cristina Vodiță ${ }^{1,2}$, Doina Lucia Ghergic ${ }^{1,3}$, Emanuel Alin Vodiță ${ }^{1,2}$, Raluca Monica Comăneanu ${ }^{1,3}$, \\ Laurența Lelia Mihai ${ }^{3}$ \\ ${ }^{1}$ Şcoala Doctorală - Domeniul Medicină Dentară, IOSUD „Titu Maiorescu“, Bucureşti, România \\ ${ }^{2}$ Clinica stomatologică „Dr. Vodiță“, Bucureşti, România \\ ${ }^{3}$ Facultatea de Medicină Dentară, Universitatea „Titu Maiorescu“, Bucureşti, România
}

\begin{abstract}
Objectives. The study aimed to detect the presence/quantification of the 12 bacterial strains more frequently involved in the occurrence and aggravation of periodontal disease in a group of patients.

Material and method. The study included 55 patients of both sexes, from the portfolio of the „Dr. Vodiță“ Dental Clinic, with chronic marginal periodontitis, who had not been under regular dental control and hygiene for at least 2 years. During the first treatment session, fluid was collected from each patient from the periodontal bags using sterile paper cones from the collection putty. Subsequently, fluid-soaked paper cones from periodontal bags were sent to the Genetic Lab in Bucharest for DNA extraction and quantification of 12 bacterial species, more common in the etiology of periodontal disease. For the correctness of the results obtained, it is necessary that patients have not taken antibiotics in the last 3 weeks. The data were analyzed and statistically processed with the Microsoft Excel 2016 program.

Results. The least common bacteria found were from the species: Capnocytophaga ochracea, Aggregatibacter actinomycetemcomitans, Eikanella corrodens and Campylobacter rectus, closely followed by Capnocytophaga gingivalis, Prevotella intermedia and Capnocytophaga sputigena. The rest of the bacterial species were detected much more frequently.

Discussions. In the analyzed group there was no monoinfection with Aggregatibacter actinomycetemcomitans. Porphyromonas gingivalis had an important presence in the studied group, registering increased levels in $89 \%$ of cases. In our group, Treponema denticola was present in increased amounts in $76.36 \%$ of cases. Tannerella forsythia was present in $92.72 \%$ of cases in elevated concentrations. Eikanella corrodens and Campylobacter rectus were present in $18.18 \%$ of the cases studied in high quantities. Prevotella intermedia was present in significant amounts in $34.54 \%$ of cases. Fusobacterium nucleatum was present in high concentrations in $98.18 \%$ of the cases studied. Prevotella nigrescens was present in increased amounts in $56.36 \%$ of cases. Capnocytophaga ochracea was present in $9.09 \%$ of cases in high amounts, Capnocytophaga sputigena in $38.18 \%$ of cases, and Capnocytophaga gingivalis was detected in $24.45 \%$ of cases.

Conclusions. From the class of bacteria with high pathogenicity, we most frequently encountered in the studied group Tannerella forsythia. From the class of bacteria with moderate pathogenicity, we encountered the most common Fusobacterium nucleatum. From the class of bacteria with low pathogenicity, we encountered the most common Capnocytophaga sputigena. In order to validate the results obtained, it is necessary to extend the study to a larger number of patients.
\end{abstract}

Keywords: periodontitis, microbial germs, PCR

\section{REZUMAT}

Obiective. Studiul a avut drept scop detectarea prezenței / cuantificarea celor 12 tulpini bacteriene implicate mai frecvent în apariția și agravarea îmbolnăvirilor parodontale la un lot de pacienți.

Material şi metodă. În studiu au fost incluși 55 pacienți de ambele sexe, din portofoliul Clinicii Stomatologice Dr. Vodiță, cu parodontopatii marginale cronice, care nu mai fuseseră la control periodic stomatologic și igienizare de minim 2 ani. În cadrul primei ședințe de tratament, de la fiecare pacient a fost recoltat fluid din pungile parodontale cu ajutorul unor conuri de hârtie sterile, din chitul de recoltare. Ulterior, conurile de hîrtie îmbibate cu fluid din pungile parodontale au fost trimise la laboratorul Genetic Lab din București pentru extracția ADN și cuantificarea a 12 specii bacteriene, întâlnite mai frecvent în etiologia bolii parodontale. Pentru corectitudinea rezultatelor obținute, este necesar ca pacienții să nu fi luat antibiotice în ultimele 3 săptămâni. Datele au fost analizate şi prelucrate statistic cu programul Microsoft Excel 2016. 
Rezultate. Cele mai puțin frecvente bacterii depistate au fost din speciile: Capnocytophaga ochracea, Aggregatibacter actinomycetemcomitans, Eikanella corrodens şi Campylobacter rectus, urmate îndeaproape de Capnocytophaga gingivalis, Prevotella intermedia și Capnocytophaga sputigena. Restul speciilor bacteriene au fost depistate mult mai frecvent.

Discuții. La lotul analizat nu a existat o monoinfecţie cu Aggregatibacter actinomycetemcomitans. Porphyromonas gingivalis a avut o prezenţă importantă la lotul studiat, înregistrând niveluri crescute în $89 \%$ dintre cazuri. La lotul nostru, Treponema denticola a fost prezentă în cantităţi crescute în $76,36 \%$ dintre cazuri. Tannerella forsythia a fost prezentă în 92,72\% dintre cazuri în concentraţii crescute. Eikanella corrodens şi Campylobacter rectus au foste prezente în 18,18\% dintre cazurile studiate în cantităţi crescute. Prevotella intermedia a fost prezentă în cantităţi importante în 34,54\% dintre cazuri. Fusobacterium nucleatum a fost prezentă în concentraţii ridicate în 98,18\% dintre cazurile luate în studiu. Prevotella nigrescens a fost prezentă în cantităţi crescute în $56,36 \%$ dintre cazuri. Capnocytophaga ochracea a fost prezentă în 9,09\% dintre cazuri în cantităţi crescute, Capnocytophaga sputigena în 38,18\% dintre cazuri, iar Capnocytophaga gingivalis a fost depistată în $24,45 \%$ dintre cazuri.

Concluzii. Din clasa bacteriilor cu patogenitate ridicată, cel mai frecvent am întâlnit la lotul studiat Tannerella forsythia. Din clasa bacteriilor cu patogenitate moderată, am întâlnit cel mai frecvent Fusobacterium nucleatum. Din clasa bacteriilor cu patogenitate redusă, am întâlnit cel mai frecvent Capnocytophaga sputigena. Pentru validarea rezultatelor obținute, este necesară extinderea studiului la un număr mai mare de pacienți.

Cuvinte cheie: parodontită, germeni microbieni, PCR

\section{INTRODUCERE}

Boala parodontală reprezintă afectarea de origine infecțioasă, polimicrobiană, a structurilor parodontale, iniţiată de biofilmul dentar, ce se soldează cu leziuni cronice inflamatorii, cu evoluție progresivă, ce duc la afectarea structurilor de suport și, în final, la pierderea dinţilor.

Biofilmul dentar este definit ca un depozit aderent de suprafețele orale, alcătuit din comunități complexe microbiene, cuprinse intr-o matrice extracelulară [1]. Clinic, biofilmul poate fi împărțit în supragingival și subgingival, cele două componente fiind delimitate de marginea liberă gingivală.

Ca urmare a condițiilor diferite ale celor două habitate, compoziția lor microbială este diferită [2].

Potențialul patogen al bacteriilor orale nu este identic pentru toate tipurile și la toți subiecții. La indivizii sănătoși parodontal, patogenii parodontali colonizează în număr redus și nu induc leziuni, făcând parte din flora orală normală microbiană. Inițierea parodontitei se produce odată cu modificarea proporţiei bacteriilor subgingivale [3].

Flora parodontală microbiană este heterogenă [4,5] şi cuprinde peste 400 de specii subgingivale, dintre care fiecare individ prezintă doar o anumită proporție. Orice prelevare de placă subgingivală cuprinde aproximativ 30 specii bacteriene diferite [6].

Bacteriile patogene implicate în instalarea și agravarea bolii parodontale se clasifică în 3 categorii:

a) Bacterii cu patogenitate ridicată: Aggregatibacter actinomycetemcomitans, Porphyromonas gingivalis, Treponema denticola, Tannerella forsythia

b) Bacterii cu patogenitate moderată: Eikanella corrodens, Campylobacter rectus, Prevotella intermedia, Fusobacterium nucleatum, Prevotella nigrescens

c) Bacterii cu patogenitate redusă: Capnocytophaga ochracea, Capnocytophaga sputigena, Capnocytophaga gingivalis.

Bacteriile din prima categorie sunt considerate puternic asociate cu dezvoltarea și progresia formelor agresive de boală parodontală, prezentând efecte patogene chiar și în concentrații mici.

Bacteriile din cea de-a doua categorie se asociază moderat cu dezvoltarea bolii parodontale și se identifică în special în formele cronice.

Bacteriile din cea de-a treia categorie au o asociere minoră cu boala parodontală, sunt identificate atât în situsurile active, cât și în formele cronice ale bolii parodontale.

Tratamentul bolii parodontale cuprinde manopere nonchirurgicale (îndepărtarea plăcii bacteriene, tratament antibiotic, decontaminări laser etc.) şi chirurgicale (chirurgie parodontală, grefarea defectelor osoase profunde).

\section{SCOP}

Scopul studiului nostru a fost detectarea prezenței/cuantificarea celor 12 tulpini bacteriene implicate mai frecvent în apariția și agravarea îmbolnăvirilor parodontale la un lot de pacienţi.

Cuantificarea speciilor bacteriene identificate în formele bolii parodontale este utilă pentru stabilirea celor mai frecvente tulpini bacteriene care de- 
termină manifestări mai agresive la variate populații.

\section{MATERIALE ŞI METODE}

În studiu, au fost incluși 55 pacienți de ambele sexe, cu parodontopatii marginale cronice, care nu mai fuseseră la control periodic stomatologic și igienizare de minimum 2 ani.

În Clinica stomatologică „Dr. Vodiță“", au fost completate fișe de observație și tratament în care au fost consemnate:

- Vârsta

- Sexul

- Statutul de fumător sau nefumător

- Condiții medicale relevante (diabet, imunodepresie, boli parodontale ereditare, afecțiuni cardiovasculare)

- Condiții fiziologice relevante (sarcina)

- Descrierea simptomatologiei parodontale (prezența sau nu a sângerărilor gingivale spontane sau la atingere, modificări locale de culoare, inflamație, resorbție osoasă, halenă)

- Gradul bolii parodontale (tip I - gingivită, tip II - parodontită uşoară, tip III - parodontită moderată, tip IV - parodontită avansată, tip V - parodontită refractară la tratament)

- Întinderea afectării parodontale (parodontită localizată sau generalizată).

Pacienții au semnat un formular de consimțământ prin care au fost de acord ca rezultatele analizelor efectuate să poată fi utilizate în scopuri științifice, cu protejarea identităţii lor.

În cadrul primei ședințe de tratament, de la fiecare pacient a fost recoltat fluid din pungile parodontale cu ajutorul unor conuri de hârtie sterile, din chitul de recoltare. Conurile de hârtie au fost introduse în câte o pungă parodontală mai adâncă și menținute pentru 10 secunde pentru a se îmbiba cu fluid. Ulterior, conurile de hîrtie au fost introduse pentru fiecare pacient în câte un tub de transfer steril și au fost trimise la laboratorul Genetic Lab din București pentru extracția ADN și cuantificarea speciilor bacteriene prezente. Pentru corectitudinea rezultatelor obținute, este necesar ca pacienții să nu fi luat antibiotice în ultimele 3 săptămâni.

În laborator, s-a urmărit detectarea prezenței în probele recoltate a celor 12 specii bacteriene implicate în instalarea și agravarea bolii parodontale [Aggregatibacter actinomycetemcomitans (Aa), Porphyromonas gingivalis (Pg), Treponema denticola (Td), Tannerella forsythia (Tf), Eikanella corrodens (Ek), Campylobacter rectus (Cr), Prevotella intermedia (Pi), Fusobacterium nucleatum (Fn), Prevotella nigrescens (Pn), Capnocytophaga ochracea (Co), Capnocytophaga sputigena (Cs) și Capnocytophaga gingivalis $(\mathrm{Cg})]$.

Pentru a extrage ADN-ul bacterian, în cadrul laboratorului, conurile de hârtie au fost ținute peste noapte în $1 \mathrm{ml}$ de soluție PBS 1,5 x. Sedimentul bacterian s-a obținut prin vortexarea timp de 10 minute a conurilor de hârtie suspendate în soluție PBS, iar soluția obținută a fost centrifugată 10 minute la $16.000 \mathrm{G}$.

S-au reținut $200 \mu 1$ de supernatant PBS cu sedimentul bacterian (resuspendat), iar materialul genetic a fost extras cu ajutorul Viral Kit I (Favorgen), conform recomandărilor producătorului. S-a adăugat probelor de $200 \mu 1 \mathrm{PBS}$ câte $570 \mu \mathrm{l}$ de tampon VNE (buffer îmbogățit cu AND-carrier), mostrele au fost incubate 10 minute la temperatura camerei, după care s-au adăugat peste fiecare probă $570 \mu 1$ etanol pur. Soluțiile rezultate au fost încărcate în coloane individuale separatoare de

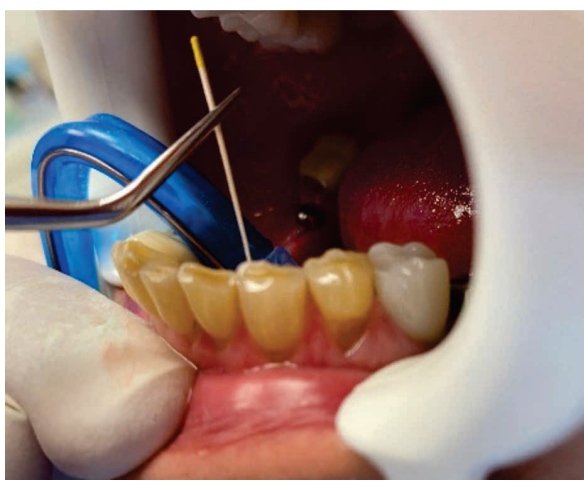

a

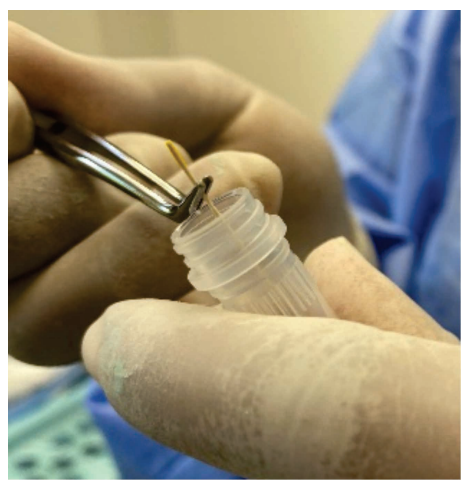

b

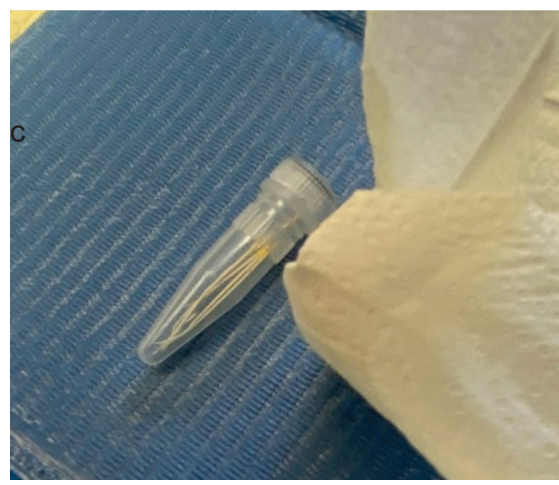

C

FIGURA 1A,B,C. Recoltarea fluidului din pungile parodontale ş ambalarea în tub de transfer 
ADN, care au fost spălate cu soluție tampon I, apoi cu soluție tampon II, iar în final ADN-ul a fost eluat în apă preîncălzită, liberă de nucleaze.

Cuantificarea concentrațiilor bacteriene fost realizată cu ajutorul LightCycler 2.0 (Roche) prin PCR cantitativ în timp real. S-au efectuat reacții PCR țintite pentru fiecare specie bacteriană dintre cele 12 testate. Amplificarea PCR a fost efectuată prin monitorizarea semnalului fluorescent al SYBR Green I. Ciclul de amplificare în care semnalul fluorescent a depăşit nivelul de prag a fost marcat ca estimator al cantității de material ADN prezent în probă, pentru fiecare specie bacteriană testată.

Încărcarea bacteriană cantitativă a probelor a fost obținută prin compararea intensității semnalului fluorescent al fiecărei specii testate cu semnalul fluorescent qPCR al unor concentrații bacteriene cunoscute (curbă standard pentru Porphiromonas gingivalis). Prin extrapolarea pe curba standard a curbei fiecărei specii testate, s-a obținut estimarea numărului de celule bacteriene colectate din pungile parodontale.

Pentru a deosebi amplificările de material ADN specific țintelor căutate față de amplificările PCR nespecifice, s-a utilizat analiza HRM, ce monitorizează punctul termic de înjumătățire al semnalului fluorescent specific disocierii catenelor ADN ale ampliconilor obținuți în cazul fiecărei specii bacteriene analizate.

Pe măsura denaturării $\mathrm{ADN}$, fluoroforul SYBR Green, ataşat la produsul PCR aflat în fiecare tub de testare, se va desprinde de ADN și își va reduce semnalul fluorescent. Momentul în care se atinge $50 \%$ din semnalul fluorescent maxim corespunde unei anumite temperaturi, iar fiecare bacterie prezintă o temperatură specifică de denaturare a ampliconului propriu.

Analiza statistică a datelor obținute s-a realizat utilizând softul Microsoft Excel 2016.

\section{REZULTATE}

Vârsta medie a lotului analizat a fost de 51,02 ani, $54,5 \%$ fiind femei.

În figura 2 sunt precizate intervalele (nedetectabil, scăzut sau ridicat) în care au fost detectate cele 12 tipuri de bacterii analizate.

La lotul analizat, toți pacienții au negat prezența condițiilor medicale sau fiziologice relevante pentru instalarea și evoluția bolii parodontale sau a obiceiurilor vicioase de tipul fumatului.

Simptomatologia parodontală depistată a fost reprezentată, în ordinea descrescătoare a frecvenței, de: deteriorare osoasă, inflamație, halenă, modificare de culoare a gingiei și sângerare.

Pacienții au fost încadrați, în ordinea descrescătoare a frecvenței, în parodontită avansată (tip IV), moderată (tip III) și incipientă (tip II). Niciun pacient din lotul analizat nu prezenta alergie la antibiotice.

La lotul analizat, nu am depistat o corelație semnificativă între prezența Aggregatibacter actinomycetemcomitans și a celorlaltor 3 specii bacteriene cu patogenitate ridicată. În schimb, Porphyromonas gingivalis, Treponema denticola și

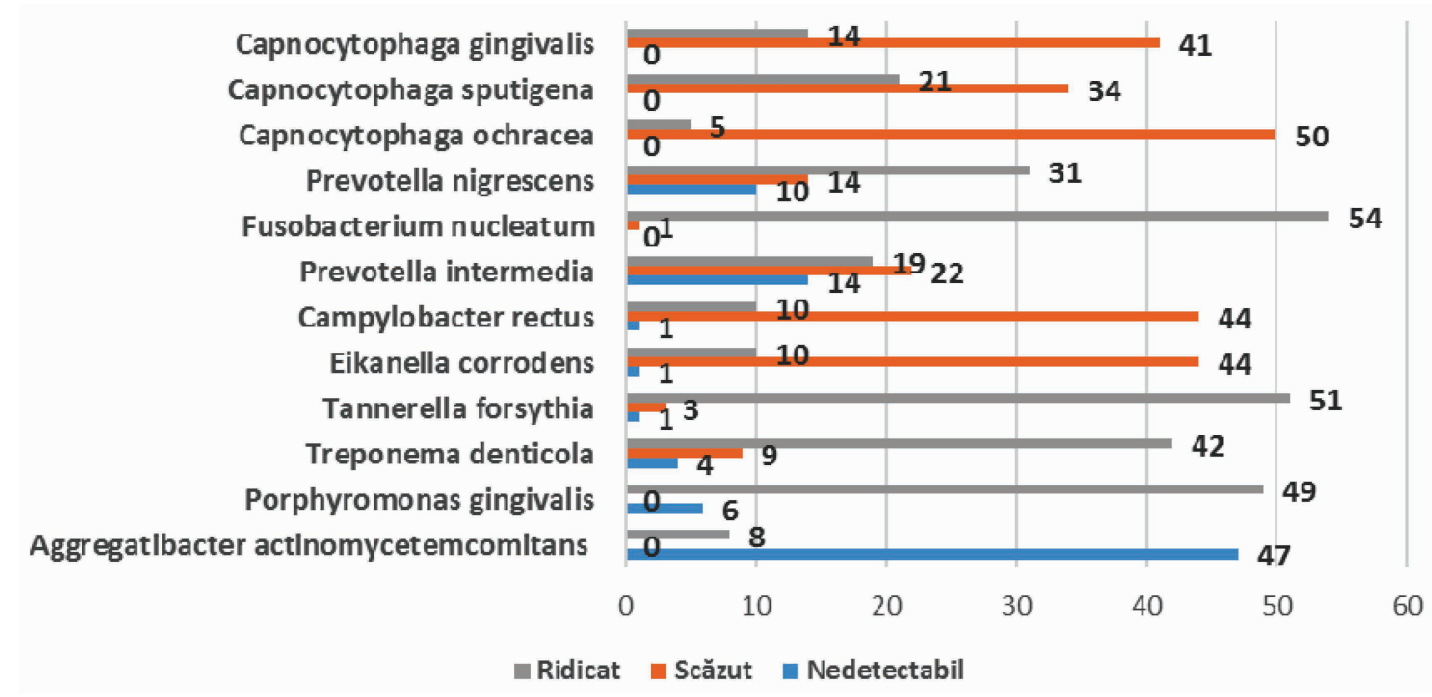

FIGURA 2. Speciile de bacterii cuantificate în probele recoltate 


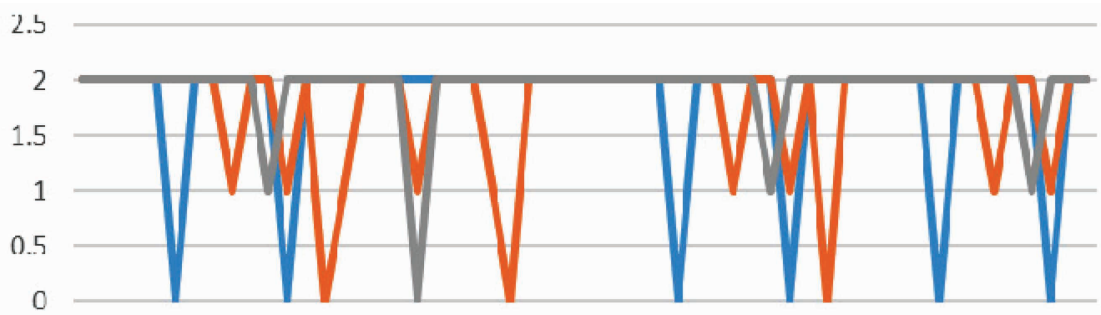

1357791113151719212325272931333537394143454749515355

$\longrightarrow \mathrm{Pg}=\mathrm{Td}=\mathrm{Tf}$

FIGURA 3. Corelaţii între prezenţa Porphyromonas gingivalis, Treponema denticola şi Tannerella forsythia la lotul analizat (unde 0 este nedectabil, 1 este moderat, 2 este ridicat)

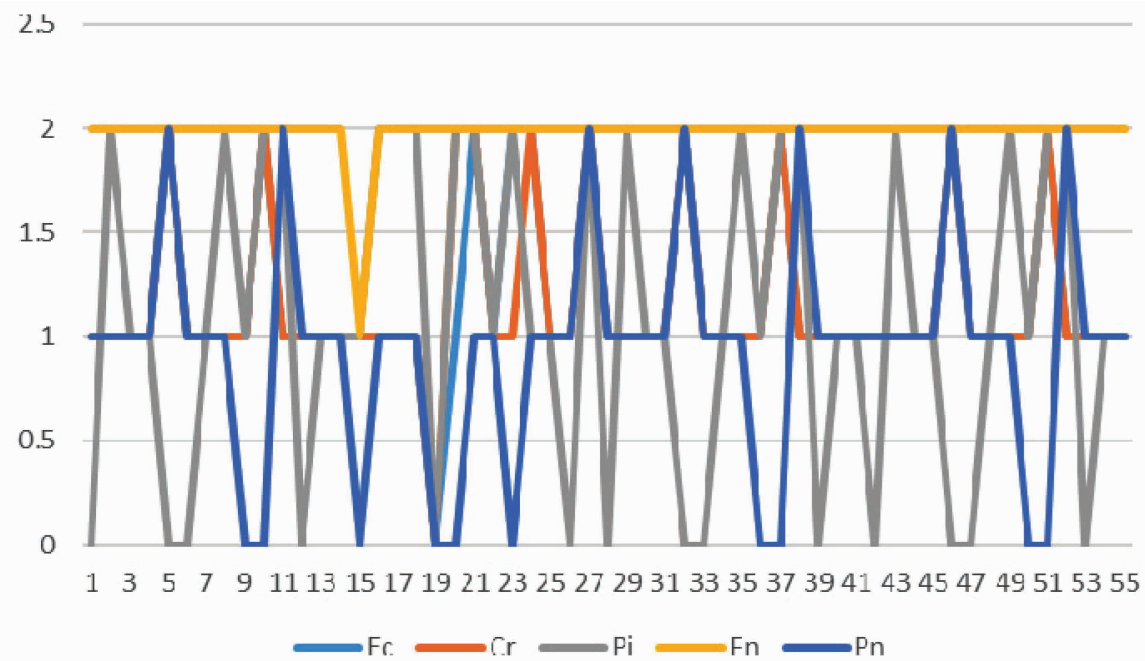

FIGURA 4. Corelaţii între prezenţa germenilor bacterieni cu patogenitate moderată la lotul analizat (unde 0 este nedectabil, 1 este moderat, 2 este ridicat)

2.5

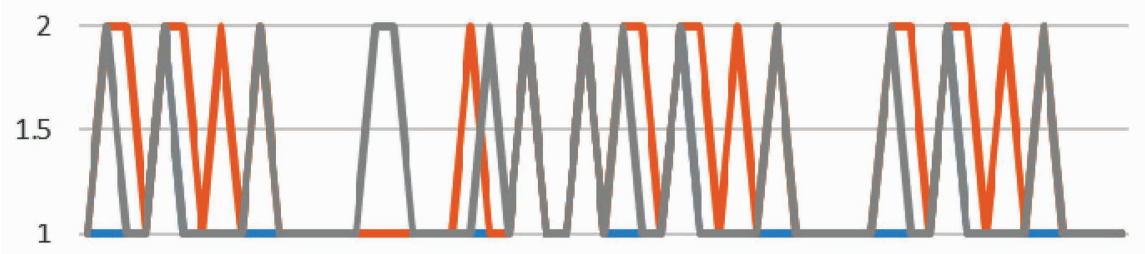

0.5

0

13557991113151719212325272931333537394143454749515355

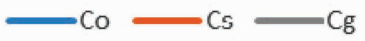

FIGURA 5. Corelaţii între prezenţa germenilor bacterieni cu patogenitate redusă la lotul analizat (unde 0 este nedectabil, 1 este moderat, 2 este ridicat)

Tannerella forsythia au avut o prezență constantă în situsurile analizate (figura 3 ).

Cel mai puţin frecvente bacterii depistate au fost din speciile: Capnocytophaga ochracea, Aggregatibacter actinomycetemcomitans, Eikanella corrodens și Campylobacter rectus, urmate îndeaproape de Capnocytophaga gingivalis, Prevotella intermedia și Capnocytophaga sputigena. Restul speciilor bacteriene au fost depistate mult mai frecvent (figura 4, figura 5). 


\section{DISCUŢII}

Aggregatibacter actinomycetemcomitans este un cocobacil non-motil, Gram-negativ, capnofil (necesită pentru creștere dioxid de carbon), facultativ anaerob, zaharolitic [1,7-9]. Deși parodontita agresivă localizată nu este produsă de monoinfecția cu Aa, bacteria este considerată un parodontopatogen major. La lotul analizat, nu a existat o monoinfecţie cu Aa.

Porphyromonas gingivalis [10-13] este specia bacteriană dominantă în parodontitele juvenile generalizate, în parodontitele rapid progresive agresive, in gingivostomatita ulcero-necrotică și în multe tipuri de parodontite cronice. Este o specie Gram-negativă, imobilă, sub formă de cocobacili, cu toxicitate mult mai mare față de alte bacterii Gram-negative. Pg a avut o prezenţă importantă la lotul studiat, înregistrând niveluri crescute în $89 \%$ dintre cazuri.

Treponema denticola [14-16] sunt bacterii spiralate Gram-negative, ce conțin smocuri de flageli ce le permit efectuarea de mișcări variate și complexe, chiar și în medii vâscoase. Se cultivă în condiții de strictă anaerobioză. Sunt prezente în cantităţi semnificative în forme severe de parodontopatii. La lotul nostru, Td a fost prezentă în cantităţi crescute în $76,36 \%$ dintre cazuri.

Tannerella forsythia [17-20] este un bacil Gram-negativ, imobil și nesporulat. Se cultivă dificil, fie pe medii pe care se cultivă concomitent $F u$ sobacterium nucleatum, fie pe medii care sunt suplimentate cu acid muramic, în condiții stricte de anaerobioză. Bacteria este prezentă în formele agresive ale gingivitelor și parodontitelor. La lotul studiat, Tf a fost prezentă în $92,72 \%$ dintre cazuri în concentraţii crescute.

Eikanella corrodens [21] este o specie de bacili Gram-negativi, facultativ anaerobi, care se găsește la pacienții cu forme agresive de parodontopatii.

Campylobacter rectus [22,23] este o bacterie Gram-negativă care prezintă un aspect helicoid și prezintă o mobilitate crescută ca urmare a prezenței unui cil polar. Este bacteria dominantă la bolnavii SIDA ce prezintă parodontită marginală ulcero- necrotică, dar se întâlnește și în parodontopatii cronice cu distrucții avansate.

Ec şi $\mathrm{Cr}$ au foste prezente în 18,18\% dintre cazurile studiate în cantităţi crescute.

Prevotella intermedia [24,25] este un cocobacil Gram-negativ, prezent în gingivostomatita ulceronecrotică și în parodontopatii cronice avansate. În studiul nostru, Pi a fost prezentă în cantităţi importante în $34,54 \%$ dintre cazuri.

Fusobacterium nucleatum [26] este un bacil Gram-negativ, dispus izolat, sub formă de pereche sau în snopi. Sunt izolate în gigivitele ulcero-necrotice și în formele de boală parodontală progresivă. La lotul nostru, Fn a fost prezentă în concentraţii ridicate în $98,18 \%$ dintre cazurile luate în studiu.

Prevotella nigrescens [27] este un bacil Gramnegativ, fără motilitate, cu rol patogen în parodontite și gingivite. Pn a fost prezentă în cantităţi crescute în 56,36\% dintre cazuri.

Capnocytophaga ochracea, Capnocytophaga sputigena și Capnocytophaga gingivalis sunt specii de bacili Gram-negativi ce prezintă uneori filamente și se izolează în formele severe de parodontopatii [28]. Co a fost prezentă în 9,09\% dintre cazuri în cantităţi crescute, Cs în 38,18\% dintre cazuri, iar Cg a fost depistată în $24,45 \%$ dintre cazuri.

\section{CONCLUZII}

Din clasa bacteriilor cu patogenitate ridicată, cel mai frecvent am întâlnit la lotul studiat Tannerella forsythia. Din clasa bacteriilor cu patogenitate moderată, am întâlnit cel mai frecvent Fusobacterium nucleatum. Din clasa bacteriilor $\mathrm{cu}$ patogenitate redusă, am întâlnit cel mai frecvent Capnocytophaga sputigena. Pentru validarea rezultatelor obținute, este necesară extinderea studiului la un număr mai mare de pacienți.

\section{Notă}

Toţi autorii au avut o contribuţie egală la publicarea acestui material.

Conflict of interest: none declared Financial support: none declared 


\section{BIBLIOGRAFIE}

1. Ionescu E și colab. Manual pentru rezidențiat. Ed Universitară "Carol Davila“, 2021.

2. Teughels W, et al. Biofilm and Periodontal Microbiology. In: Newman M, Takei H, Klokkevold P, Carranza F. Newman and Carranza's Clinical Periodontology, 13th edition. Elsevier Saunders, 2019.

3. Berezow AB, Darveau RP. Microbial shift and periodontitis. Periodontol 2000. 2011 Feb;55(1):36-47.

4. Socransky SS, Haffajee AD. The bacterial etiology of destructive periodontal disease: current concepts. J Periodontol. 1992 Apr; 63(4 Suppl):322-31.

5. Darveau RP. The oral microbial consortium's interaction with the periodontal innate defense system. DNA Cell Biol. 2009 Aug;28(8):389-95.

6. Socransky SS, Haffajee AD. Dental biofilms: difficult therapeutic targets. Periodontol 2000. 2002;28:12-55.

7. Oscarsson J, DiRienzo J, Johansson A. Editorial Comments to the Special Issue: „Aggregatibacter actinomycetemcomitans-GramNegative Bacterial Pathogen". Pathogens. 2020 Jun 4;9(6):441.

8. Ardila CM, Bedoya-García JA. Antimicrobial resistance of Aggregatibacter actinomycetemcomitans, Porphyromonas gingivalis and Tannerella forsythia in periodontitis patients. J Glob Antimicrob Resist. 2020 Sep;22:215-218.

9. Jensen $A B$, Isidor $F$, Lund $M$, Væth $M$, Johansson $A$, Lauritsen $N N$, Haubek D. Prevalence of Aggregatibacter actinomycetemcomitans and Periodontal Findings among 14 to 15-Year Old Danish Adolescents: A Descriptive Cross-Sectional Study. Pathogens. 2020 Dec 16;9(12):1054.

10. Mei F, Xie M, Huang X, Long Y, Lu X, Wang X, Chen L. Porphyromonas gingivalis and Its Systemic Impact: Current Status. Pathogens. 2020 Nov 13;9(11):944.

11. Olsen I, Kell DB, Pretorius E. Is Porphyromonas gingivalis involved in Parkinson's disease? Eur J Clin Microbiol Infect Dis. 2020 Nov;39(11):2013-2018.

12. Mulhall $\mathrm{H}$, Huck $\mathrm{O}$, Amar S. Porphyromonas gingivalis, a LongRange Pathogen: Systemic Impact and Therapeutic Implications. Microorganisms. 2020 Jun 9;8(6):869.

13. Mulhall H, Huck O, Amar S. Porphyromonas gingivalis, a LongRange Pathogen: Systemic Impact and Therapeutic Implications. Microorganisms. 2020 Jun 9;8(6):869.

14. Kin LX, Butler CA, Slakeski N, Hoffmann B, Dashper SG, Reynolds EC. Metabolic cooperativity between Porphyromonas gingivalis and Treponema denticola. J Oral Microbiol. 2020 Aug 24;12(1):1808750.

15. Kurniyati K, Li C. Genetic Manipulations of Oral Spirochete Treponema denticola. Methods Mol Biol. 2021;2210:15-23.

16. Laiola M, De Filippis F, Vitaglione P, Ercolini D. A Mediterranean Diet Intervention Reduces the Levels of Salivary Periodontopathogenic Bacteria in Overweight and Obese Subjects. Appl Environ Microbiol. 2020 Jun 2;86(12):e00777-20.
17. Hampelska K, Jaworska MM, Babalska Z飞, Karpiński TM. The Role of Oral Microbiota in Intra-Oral Halitosis. J Clin Med. 2020 Aug 2;9(8):2484.

18. Miralda I, Uriarte SM. Periodontal Pathogens' strategies disarm neutrophils to promote dysregulated inflammation. Mol Oral Microbiol. 2021 Apr;36(2):103-120.

19. Menini M, Delucchi F, Bagnasco F, Pera F, Di Tullio N, Pesce P. Analysis of the Subgingival Microbiota in Implant-Supported Full-Arch Rehabilitations. Dent J (Basel). 2020 Sep 5;8(3):104.

20. Liukkonen J, Gürsoy UK, Könönen E, Akhi R, Salminen A, Liljestrand JM, et al. Immunological and Microbiological Profiling of Cumulative Risk Score for Periodontitis. Diagnostics (Basel). 2020 Aug 5;10(8):560.

21. Lee J, Lee JB, Song HY, Son MJ, Li L, Rhyu IC, Lee YM, Koo KT, An JS, Kim JS, Kim E. Diagnostic Models for Screening of Periodontitis with Inflammatory Mediators and Microbial Profiles in Saliva. Diagnostics (Basel). 2020 Oct 14;10(10):820.

22. Thomas C, Nothaft H, Yadav R, Fodor C, Alemka A, Oni O, Bell M, Rada B, Szymanski CM. Characterization of ecotin homologs from Campylobacter rectus and Campylobacter showae. PLoS One. 2020 Dec 30;15(12):e0244031.

23. Lee Y, Hong Y, Kim B, Lee D, Kim S, Rhyu IC. Efficacy of salivary versus subgingival bacterial sampling for the detection and quantification of periodontal pathogens. J Periodontal Implant Sci. 2020 Dec;50(6):358-367.

24. Yamashita Y, Nagaoka K, Kimura H, Suzuki M, Fukumoto T, et al. Pathogenic Effect of Prevotella intermedia on a Mouse Pneumonia Model Due to Methicillin-Resistant Staphylococcus aureus With Up-Regulated a-Hemolysin Expression. Front Microbiol. 2020 Oct 7;11:587235.

25. Du Q, Ma X. Research progress of correlation between periodontal pathogens and systemic diseases. Nan Fang Yi Ke Da Xue Xue Bao. 2020 May 30;40(5):759-764.

26. Abed J, Maalouf N, Manson AL, Earl AM, Parhi L, Emgård JEM, Klutstein M, et al. Colon Cancer-Associated Fusobacterium nucleatum May Originate From the Oral Cavity and Reach Colon Tumors via the Circulatory System. Front Cell Infect Microbiol. 2020 Aug 7;10:400.

27. Irshad M, Alam MK, Alawneh A, Alhadi MA, Alhadi AA, Almunajem YS, et al. Characterization and Antimicrobial Susceptibility of Pathogens Associated with Periodontal Abscess. Antibiotics (Basel). 2020 Sep 29;9(10):654.

28. Poirier TP, Tonelli SJ, Holt SC. Ultrastructure of gliding bacteria: scanning electron microscopy of Capnocytophaga sputigena, Capnocytophaga gingivalis, and Capnocytophaga ochracea. Infect Immun. 1979 Dec;26(3):1146-58. 